Bryn Mawr College

Scholarship, Research, and Creative Work at Bryn Mawr College

Education Program Faculty Research and

Scholarship

Education Program

2002

\title{
Authorizing Students' Perspectives: Toward Trust, Dialogue, and Change in Education
}

Alison Cook-Sather

Bryn Mawr College, acooksat@brynmawr.edu

Let us know how access to this document benefits you.

Follow this and additional works at: http://repository.brynmawr.edu/edu_pubs

Part of the Education Commons

\section{Custom Citation}

Cook-Sather, Alison. "Authorizing Students' Perspectives: Toward Trust, Dialogue, and Change in Education." Educational Researcher 31, no. 4 (2002): 3-14.

This paper is posted at Scholarship, Research, and Creative Work at Bryn Mawr College. http://repository.brynmawr.edu/edu_pubs/17

For more information, please contact repository@brynmawr.edu. 
Authorizing Students' Perspectives: Toward Trust, Dialogue, and Change in Education

Alison Cook-Sather

(Educational Researcher, Vol. 31, No. 4, May 2002, pp. 3-14)

Since the advent of formal education in the United States, both the educational system and that system's every reform have been premised on adults' notions of how education should be conceptualized and practiced. There is something fundamentally amiss about building and rebuilding an entire system without consulting at any point those it is ostensibly designed to serve. The inefficacy of this approach becomes increasingly apparent as we move into the $21^{\text {st }}$ century. As the pace of life accelerates, as the population becomes increasingly diverse, and as the media through which we teach, learn, and work become more complex, more than ever before, those of us who count ourselves educators and educational researchers must seriously question the assumption that we know more than the young people of today about how they learn or what they need to learn in preparation for what lies in the decades ahead. It is time that we count students among those with the authority to participate both in the critique and in the reform of education.

At the root of the terms that underlie the following discussion - authorize, authority, author, and authoritative - is power: "the ability to take one's place in whatever discourse is essential to action and the right to have one's part matter" (Heilbrun, 1988, p. 18). For students to have such an ability, those of us currently invested with authority must confront "the power dynamics inside and outside our classrooms [that make] democratic dialogue impossible" (Ellsworth, 1992, p. 107). We must use our power "in an attempt (that might not be successful) to help others exercise power" (Gore, 1992, p. 59). This call to authorize student perspectives is a call to count students among those who have the knowledge and the position to shape what counts as education, to reconfigure power dynamics and discourse practices within existing realms of conversation about education, and to create new forums within which students can 
embrace "the political potential of speaking out on their own behalf" (Lewis, 1993, p. 44).

The work of authorizing student perspectives is essential because of the various ways that it can improve current educational practice, re-inform existing conversations about educational reform, and point to the discussions and reform efforts yet to be undertaken. Authorizing student perspectives can directly improve educational practice because when teachers listen to and learn from students, they can begin to see the world from those students' perspectives (Clark, 1995; Davies, 1982; Finders, 1997; Heshusius, 1995). This is more than simply an interesting experience; it can help teachers make what they teach more accessible to students (Commeyras, 1995; Dahl, 1995; Davies, 1982; Lincoln, 1995; Johnson \& Nicholls, 1995). Furthermore, it can contribute to the conceptualization of teaching, learning, and the ways we study them as more collaborative processes (Corbett \& Wilson, 1995; Nicholls \& Thorkildsen, 1995; Oldfather \& Thomas, 1998; Shor, 1992). When students are taken seriously and attended to as knowledgeable participants in important conversations, they feel empowered (Hudson-Ross, Cleary, \& Casey, 1983) and motivated to participate constructively in their education (Colsant, 1995; Oldfather et. al, 1999; Sanon, Baxter, Fortune \& Opotow, 2001; Shultz \& Cook-Sather, 2001).

Authorizing student perspectives introduces into critical conversations the missing perspectives of those who experience daily the effects of existing educational policies-inpractice. Because students "have been silenced all their lives" (Giroux, 1992, p. 158), they have singular and invaluable views on education from which both adults and students themselves can benefit (Cook-Sather \& Shultz, 2001a and 2001b; Fine \& Sandstrom, 1988; Oldfather, 1995, 1999). Students have a unique perspective on what happens in school and classrooms (Cook-Sather \& Shultz, 2001a; Weis \& Fine, 1993; Willis, 1977) and on the dynamics between their schools and their communities (Nespor, 1997) that inform what happens in those schools and classrooms. As long as we exclude these perspectives from our conversations about schooling and how it needs to change, our efforts at reform we will be based on an incomplete picture of life in classrooms and schools and how that life could be improved. 
Finally, authorizing student perspectives recognizes and responds to the profound and unprecedented ways in which the world has changed and continues to change and the position students occupy in relation to this change. By virtue of their saturation in information technology, youth cultural media, and political currents like those set in motion by globalization, students are differently knowledgeable about the range of new modes of communication and uses for education than the teachers and educational researchers who work with them. Given their experience and perspectives, and given their position in a rapidly changing world, students must assume a different role in education and reform than they have, up until recently, been afforded.

Over the last decade some educators and educational researchers have attempted to create new roles for students and to challenge traditional notions of who has authority in and on education. Issuing from various political corners, approaching students from multiple angles, both from within and from outside the classroom, and positioning students' perspectives in relation to adults' in a variety of ways, these long overdue efforts are important both for the essential elements they embody vis-à-vis the goal of authorizing student perspectives as well as for the ways they throw into relief the work that remains to be done. To move toward more fully authorizing the perspectives of students is not simply the move to include them in existing conversations within existing power structures. Authorizing student perspectives means ensuring that there are legitimate and valued spaces within which students can speak, re-tuning our ears so that we can hear what they say, and redirecting our actions in response to what we hear. The twin challenges of authorizing student perspectives are (1) changing the structures in our minds that have rendered us disinclined to elicit and attend to students' voices and (2) changing the structures in educational relationships and institutions that have supported and been supported by this disinclination.

In the following discussion I evoke the historical images of students that have contributed to their exclusion from conversations about educational policy, practice, and reform, and I briefly discuss some of the recent efforts in interpretive research with young people that help counter these images. I then outline a variety of attempts to authorize student perspectives, and I identify in particular what about each of those efforts is critical to the present call. I conclude with a detailed discussion of how attitudes 
and institutional structures need to change if we are to more fully authorize students' perspectives on education and pursue challenging, and necessary, changes in educational policy and practice.

Historical Images of Students and Recent Challenges to Those Images

Historical images of and attitudes toward young people have helped to ensure students' exclusion from policy-making and practice-shaping conversations. Although it is rarely articulated as such, the most basic premise upon which different approaches to educational policy and practice rest is trust - whether or not adults trust young people to be good (or not), to have and put to use relevant knowledge (or not), to be responsible (or not). The educational institutions and practices that have prevailed in the United States both historically and currently reflect a basic lack of trust in students and have evolved to keep students under control and in their place: as the largely passive recipients of what others determine is education.

Since the beginning of formal education students have been designated tabulae rasa or worse, wild and dangerous spirits in whom educators must inspire fear and awe (Locke, 1823). Keeping the young under control and in their place took the form it has to this day after the industrial revolution in the late $19^{\text {th }}$ century. What Callahan (1962) termed the "cult of efficiency," which came to dominate early $20^{\text {th }}$ century thinking in all realms, including education, and the subsequent development of behaviorist models of psychology, most avidly promoted by B.F Skinner (1969), plugged learners into bolteddown desks and lock-step curricula through which they were guided by the teacher-asskilled-engineer. These movements also gave rise to all sorts of instruments to measure, evaluate, and document students' passage through "the sorting machine" that is the school (Spring, 1976; see also Kliebard, 1986).

More progressive, humanistic conceptualizations of learners based on trust in their capacities and inclinations have always run parallel to the impulse to contain and control young bodies and minds, but they have remained alternative, not the norm. Thinkers such as Rosseau (1762) and Herbart (1901) argued that children are basically good, that they should be nurtured and let to learn in their own ways at their own pace, and if properly nurtured, will act morally according to their own free will. Dewey (1964) 
built on these arguments, proposing child-centered education and rejecting the notion that children are blank slates or empty vessels to be filled. Proponents of progressive education have continued to argue that we must start "where the learner is" (Bruner, 1977, p. xi) and design educational experiences, such as those in Waldorf and Montessori schools and in pockets of progressivism in all school systems, in which students can build their own knowledge (Duckworth, 1987).

Despite the alternatives, the dominant model of education in the United States is based on metaphors that Spring (1976) and Freire (1990), respectively, critique: that learners are commodities to be classified or empty accounts to be filled. Adults' basic distrust of young people and insistence on being in control of education has meant that not only are students not authorized as knowers, they are dehumanized, reduced to products, and thus certainly devoid of those qualities that would make them authorities: trust worthiness and legitimacy as knowers.

It is difficult to develop educational approaches and systems that truly perceive and support students. Even child-centered teaching can come under criticism when the notion of "child" works to normalize and exclude those who do not fit the "ideal" (Walker, 1998). Interpretive research conducted in a variety of contexts on young people's perceptions challenges some of the old images of and attitudes toward youth and points the way for how we might better understand and support student learning. Investing young children with the authority to analyze their own educational experiences, Walsh, Tobin, \& Graue (1993) argue for the need to elicit meaning through dialogue and negotiation. In undertaking this work researchers must be cognizant of the fact that they are striving to make sense of young people's world within their own analytical frameworks (Elder, 1995). Among the challenges of this approach are managing young people's fragility and unreliability, keeping ethical considerations in mind, and remembering that the research process itself has an impact on the youth (Garbino \& Scott, 1989; Greig \& Taylor, 1999; Nespor, 1997).

The literature on images of students, models of education, and issues in research with youth includes discussion of young children through teenagers. There are, of course, different practical, developmental, and ethical considerations involved both in education and in research depending on the age and position of the young people. My purpose here 
is not to focus on best practices for students at different developmental stages. Rather, my goal is to evoke some of the issues that must be considered when including young people in conversations about education and reform. My main focus is on including middle and high school students in conversations about secondary education.

\section{A Collection of Efforts to Authorize Young People's Perspectives}

In the tradition of progressive educators, charged with the politics of social critics and critical theorists, and informed by postmodern and poststructuralist feminist challenges to problematize power relations in schools and society, calls to listen to what students have to say about school have sounded intermittently over the last decade. Just after Jonathan Kozol commented in the introduction to Savage Inequalities that "the voices of children... have been missing from the whole discussion" of education and educational reform (1991, p. 5), educational researchers began to note this absence of student perspectives and call for greater attention to students' experiences and perceptions of schooling (Erickson \& Shultz, 1992; Phelan, Davidson \& Cao, 1992). Several years passed, however, before researchers and policy-makers began to discuss the importance of not only attending to what students have to say but also to working with young people for educational reform - to "make a difference with, not for, students" (Corbett \& Wilson, 1995). Yet, at the turn of a new century, we must still question ourselves when we continue to minimize what Caparrimo (2001) calls one of the most important "variables" and what I am calling the missing voice in educational research: the student.

Challenging the legacies of students as blank slates, teachers as sole authors of what students learn, schools as sorting machines, and education as banking, a number of efforts to attend to young people's perspectives on school embody principles and strategies essential to the project of authorizing student perspectives on education. I discuss below five examples of such efforts. The purpose of this discussion is not to review exhaustively these different stances, with which most educators are familiar, nor is it to trace an evolution or to outline a hierarchy of ideas and practices regarding attending to students' perspectives. Rather, my goal is first to outline the relatively few but important stances different educators have taken on the question of how to position 
students in their own education - to aggregate the angles of vision and attendant educational practices differently positioned educators, social critics, educational researchers, and other professionals who work with young people have articulated and embodied. I then discuss how we might move beyond what has already been accomplished and toward a stance and set of practices that include students' perspectives among other authoritative perspectives on education and cede those students' perspectives the power to make change.

\section{Authorizing Student Perspectives within the Classroom: Constructivist Pedagogies}

A wide variety of pedagogical practices aggregate under the term "constructivism." I do not detail this variety here but focus rather on what all constructivist approaches have in common: the belief that students actively construct their own understandings. Constructivist pedagogies are premised on "the continual and sympathetic observation" of students' interests (Dewey, 1964, p. 436) and the development of pedagogical approaches that give students "the opportunity to explore their ideas and to try to make more sense of them" (Duckworth, 1987, p. 65). Constructivists position students as active creators of their knowledge rather than recipients of others' knowledge. Many constructivists also argue that teachers can improve their practice by listening closely to what students have to say about their learning (Commeyras, 1995; Dahl; 1995; Heshusius; 1995; Johnston \& Nicholls, 1995; Lincoln, 1995).

Constructivists contribute to the project of authorizing student perspectives the notion that students need to be authors of their own understanding and assessors of their own learning. Embracing this belief, many constructivists attend to student learning processes and feedback on their learning experiences with the goal of changing pedagogical practice so that it better facilitates that learning.

Authorizing Student Perspectives Within and Beyond the Classroom: Critical Pedagogies

Critical pedagogies not only position students as active in their own knowledge construction, they also foreground the political nature of education. Critical pedagogy focuses on critiques of social injustices and inequities and calls for the empowerment of 
students "to critically appropriate knowledge existing outside of their immediate experience in order to broaden their understanding of themselves, the world, and the possibilities for transforming the taken-for-granted assumptions about the way we live" (McLaren, 1989, p. 186). Because critical pedagogy is participatory, values-oriented, multicultural, student-centered, experiential, research-minded, and interdisciplinary (Shor, 1987, p. 22), "the learning process is negotiated, requiring leadership by the teacher and mutual teacher-student authority" (Shor, 1992, p. 16).

Whether built around adult-generated topics or around generative themes themes that are relevant to and which emerge from students' own lives (Freire, 1990) or whether reflected in multicultural and anti-racist educational theories and practices that have evolved to counter discriminatory and exclusionary practices in education (Banks, 1996; hooks; 1994; Ladson-Billings, 1994; Nieto, 2000), critical pedagogy contributes to the project of more fully authorizing student perspectives a commitment to redistributing power not only within the classroom, between teacher and students, but in society at large.

\section{$\underline{\text { Student Perspectives with/in Postmodern and Poststructuralist Feminist Pedagogies }}$}

Proponents of challenging and changing current power relations in education, some postmodern and poststructuralist feminists nevertheless caution against uncritically or unreflectively privileging student voices. Orner voices this argument clearly, warning that calls for student voice as a central component of student empowerment perpetuate "relations of domination in the name of liberation" because they do not take into great enough consideration the intersection of identity, language, context, and power that inform all pedagogical relations (1992, p. 75). Attuned to the intersection Orner describes, Ellsworth argues that "every expression of student voice [is] partial and predicated on the absence and marginalization of alternative voices" (1992, p. 103) and, reflecting on her own classroom practice, asserts that "[a]cting as if our classroom were a safe space in which democratic dialogue was possible and happening did not make it so" (1992, p. 107).

Empirical research on classrooms in which teachers have attempted to create empowering learning conditions substantiate these theoretical claims regarding classroom 
power dynamics. Studies of social class and gender dynamics in literacy classrooms (Finders, 1997) and the ways that differences can sometimes be masked (Lensmire, 1994) in classrooms that claim to be "unified learning communities" (Lewis, 2001, p. 14) reveal how complicated power dynamics are in the reality of classrooms. Addressing Orner's question - "Whose interests are served when students speak?" - Alverman et al. (1997) discuss the ways in which it is easy to talk about but difficult to interrupt gendered discursive practices in classroom talk about texts. Both Alverman (1996) and Moje \& Shepardson (1998) questioned and complicated assumptions that more student-centered pedagogical approaches necessarily empower all students, and their findings reveal a complex view of the role of power and status in discussions of literature.

The cautions articulated by these feminist theorists and researchers who have analyzed efforts at student empowerment challenge us to examine our assumptions and motives when striving to question or change power dynamics and the structures that support them. As Orner (1992) argues, educators should "attempt to recognize the power differentials present and to understand how they impinge upon what is sayable and doable in that specific context" (Orner, 1992, p. 81). Rather than be daunted by this prospect, educators must embrace what Welch (1990) calls a "feminist ethic of risk" the willingness to take small steps toward changing oppressive practices even if complete change seems or is unattainable. Even as we take these steps, however, we must be "constantly questioning the 'truth' of [our] own thought and selves" (Gore, 1992, p. 69).

\section{Authorizing Student Perspectives through Educational Researchers' Perspectives}

Although there is certainly a significant diversity of perspectives and practices within each of the realms of constructivism, critical pedagogy, and postmodern and poststructuralist feminist theory and pedagogy, each group has, respectively, a shared commitment that underlies its members' stances toward and practices of attending to student voices. Educational researchers, however, embrace all kinds of premises and have a wider variety of purposes; they do not all count themselves in the same camp. Positioned primarily outside the classroom but interested in the pedagogical interactions within classrooms, the educational researchers upon whom I focus here take a range of 
approaches to integrating student voices into their own critiques of school and to presenting the perspectives voiced as a legitimate impetus for change.

Poplin \& Weeres (1992) discuss not only the change in perspective among participants in four different school communities' reform efforts but also the actions that these communities took based on student input. Weis \& Fine invited "the voices of children and adolescents who have been expelled from the centers of their schools and the centers of our culture [to] speak" (1993, p. 2) about identity, difference, and racism from African-American students' perspectives (Cohen, 1993), prevailing discourses of female sexuality in public schools (Fine, 1993), and heterosexism and homophobia as experienced by gay, lesbian, and bisexual youth (Friend, 1993). Interested in "how adolescents view and define what is significant in affecting their school experiences," Phelan, Davidson, and Yu (1998) used student perspectives to "illuminate those aspects of students' behavior that teachers had defined as important, curious, or problematic" (p. 5). Pope (2001) also drew extensively on student perspectives to argue that "we are creating a generation of stressed out, materialistic, and miseducated students." Light (2001) foregrounds students' perspectives on how to succeed in college - perspectives which have changed advising and teaching practices at Harvard University. And Sachs (2002) draws on the perspectives of ten diverse, urban adolescents as they discuss their school experiences, family issues, societal problems, and their own attempt to deal with social inequities, and he offers suggestions for improving career decision-making behaviors in both classrooms and guidance offices.

Three themed journal issues (Knowledge Quest, May/June, 2002; Academic Exchange Quarterly, Summer, 2001; Theory into Practice, 1995) foreground student voices specifically within the context of discussions of the need to listen to those student voices, how to do so, and what it means to do so. Within the same issue of Theory into Practice, for instance, we find the argument that "[1] earning from children's voices allows us to know at a deeper level who children are as learners and, because we have that knowledge, to expand and enrich our sense of what it means to teach" (Dahl, 1995, p. 130). We also find the argument that, unless we can create a climate that is "sufficiently politically conscious and critical," we "must resist the temptation to glamorize student voices" because they "are likely to be deeply imbued with status quo values" (Shor cited 
in O'Loughlin, 1995, p. 112). These collections foreground the challenges and complexities as well as the urgency of the project of authorizing student perspectives.

These publications make two important contributions to the project of authorizing student perspectives. They all include student perspectives in the larger policy- and practice-shaping conversations from which students are generally excluded but which determine their lives in school. Many of them make visible the difficulties and contradictions as well as the illuminations that attend such a re-informing of conversations about educational policy and practice.

\section{Authorizing Student Perspectives from Social Critics' Stance}

Social critics strive to legitimate student perspectives from a different angle: in support of critiques of educational policies and practices as constructed by those neither in the classroom nor in the formal role of educator or educational researcher. Kozol's Savage Inequalities embodies this approach in its attempt to raise public awareness of race and class inequities that permeate schools. To redress the omission of student perspectives in conversations about education and reform that he critiqued, Kozol strove "to let [student] voices and their judgments and their longings find a place" in his book in the hopes that those voices would also find a place "within the nation's dialogue about their destinies" (1991, p. 5). Kotlowitz's There Are No Children Here (1991) closely attended in a similar way to the experiences of children who struggle in underfunded schools located in marginalized neighborhoods.

Writing from the perspective of critic positioned outside the classroom but dedicated to illuminating the experiences of those within classrooms, these social critics contribute to the effort to authorize student perspectives in two important ways. They produce texts that appeal to a wide readership, and thus help to inform the general public about students' experiences in school. And because these authors are not perceived by the public as educators, and thus as those with a particular bias, they can present a critical angle on the classroom than not only could not be offered by those who work within it but that also can, perhaps, be better heard than if it were offered by educators. 
Authorizing Student Perspectives through Foregrounding Students' Interpretive Frames

All of the efforts I have addressed thus far unfold within adults' interpretive frames and thus leave ultimate authority in the hands of adults. Another group of educators and educational researchers strive to shift that locus of authority and attend to young people's own interpretive frames of analysis both within classrooms and in conversations about policy and practice. This groups aims not only to include students voices and perspectives in larger conversations about policy and practice, like the educational researchers I have already mentioned, but also to have students help define the terms of those discussions. These educators employ students' voices and perspectives not only in support of their own agendas as educators and as evidence that change is needed but also as the terms according to which practice and plans for reform should be shaped.

Focusing on what can be learned from listening to children in her primary classroom talk about science, Gallas (1995) captures with the subtitle of her book not only her goal of listening but her attendant goal of reshaping her practice based on students' notions: hearing children's questions and theories, responding with curriculum. Similarly, Alverman et al. (1996) elicited middle and high school students' perceptions of text-based classroom discussions, as did Evans (2002) in her study of fifth-grade students' perceptions of their experiences participating in peer-led literature discussion groups, with the goal of having these perspectives both frame and inform recommendations for reform. In each of these studies the authors foregrounded the ways that listening to students' perspectives complicated teachers' pedagogical theories and practices and notions of how to revise them.

A long-term study conducted by Oldfather and her co-researchers traces not only students' experiences of and perspectives on being co-researchers of literacy motivations and schooling but also the process of documenting that research with students. As Oldfather and her co-authors explain, "the most crucial aspect of engaging students as partners was that they perceived themselves as co-researchers" (1999, p. 283). Students not only conducted but also analyzed, wrote up, and presented their research findings. Even in early descriptions of this project "the students speak for themselves here, without intervening interpretation" (Garcia, Kilgore, Rodriguez, \& Thomas, 1995, p. 139). 
The commitment to having students speak for themselves informed as well Wilson \& Corbett's (2001) presentation of the findings of their longitudinal study of students' experiences of and perspectives on urban school reform. Wilson \& Corbett assert that the efficacy of educational reform efforts ought to be reflected in what students say about school, and student-identified conditions and needs frame and fill the chapters of this book. As important, however, is Wilson \& Corbett's assertion that they and the students they consulted do not have all the answers. Rather, all educators need to "ask students directly" (p. 119) what they want and need in school. We need repeatedly to ask these questions of all students in every context because student answers are neither universal nor monolithic.

The commitment to asking students directly informed the composition of In Our Own Words: Students' Perspectives on School (2001). This edited volume, which includes eight chapters, each with middle or high school students as primary authors writing with the support of teachers or researchers with whom they worked, aimed "to provide a forum for middle and high school students to express in their own voices their perceptions, feelings, and insights about school" (Cook-Sather \& Shultz, 2001a, p. 1). As the editors of this collection, we urge readers not only to listen to what these studentauthors have to say about school but to turn their attention as well to students in all contexts and let what students say inform policy-making and practice-shaping decisions.

As someone who has maintained for the last eight years a project that aims to foreground students' words and interpretive frames, I can speak from inside the experience of striving to elicit students perspectives and learning to listen to and act on them. The project I have maintained in collaboration with high school based educators is called Teaching and Learning Together. Part of an undergraduate teacher preparation course, the project invites both the spoken and the written perspectives of young people into conversations about teaching and learning within the following forums: a weekly exchange of letters between pre-service teachers enrolled in the course and selected students who attend a local public high school; weekly conversations among the preservice teachers in the college classroom; and weekly conversations between the high school students and a school-based educator at the high school. Through these forums this project positions high school students as authorities among other authorities, 
including teachers, teacher educators, and published researchers. My goal is to challenge the pre-service teachers to develop beliefs and practices that are informed by what high school students, not only formal authorities on educational policy and practice, identify as critical issues in teaching and learning (Cook-Sather, 2001a and 2001b).

When one tries to alter established educational structures and power dynamics one necessarily faces a variety of difficulties, which are also opportunities. This has certainly been my experience. There are the logistical challenges of connecting educational contexts (school and college) and of collaboration with school-based educators and high school students who have demanding schedules and numerous commitments. There are the psychological challenges of convincing young adults on the brink of their first careers that they have something to learn from the people they are planning to teach. There are the intellectual challenges of fostering communication between groups of students who speak different languages and move in different educational cultures. And there are the personal challenges attendant upon any such deep questioning of established beliefs and practices. Before, during, and after each iteration of Teaching and Learning Together, one of my roles is to work through the disruptions such an approach prompts in a way that inspires all participants to keep learning. These challenges spring from the fact that authority has always been assumed to belong to educational researchers and theorists. This it is difficult even for pre-service teachers within a project that frames high school students as authorities to learn to listen to those students. As one pre-service teacher who had participated in Teaching and Learning Together put it: "being in the [college] environment for four years, I just did not think that I could learn anything from [my high school partner]. . . at the beginning I came in to the dialogue project with the idea that she could probably learn something from me" (Cook-Sather, forthcoming).

The challenge to listen at all is equaled by the challenge to learn to listen differently once one decides to listen. One pre-service teacher who had participated in Teaching and Learning Together was deeply frustrated with her dialogue partner until, as she explains, "I realized that I was expecting [my partner] to speak in my language. Amid our discussions of student voice and its value, I had neglected to realize that his learning, his method of articulation, was through experience and concrete examples. I had sought 
to give him voice while failing to hear the sound of his individual words" (Cook-Sather, 2001a, p. 31). It takes time and continued effort to change what are deeply inscribed ways of thinking about who has authority on education.

Experiences of and responses to published efforts to foreground student perspectives present similar challenges. Nespor (1997) discusses the ways in which his very presence, his entry into students' world to elicit their perspectives on that world, was disruptive (Nespor, 1997). Other researchers who have worked with students address this point from a different angle - the psychological or emotional challenge it poses to the students when they are taken out of their daily routine and "the physical [challenge of] finding a place to work in an urban school" (Cook-Sather \& Shultz, 2001, p. 167-168). Oldfather and her co-researchers (Oldfather et al. 1999, Oldfather \& Thomas, 1998) found that even when they made every effort to collaborate fully with students, issues of power and authority remained complicated. In an early discussion of writing about her collaborative research project, Oldfather (1995) describes the dilemma that Sally Thomas (her research partner) and she faced: "how can Sally and I represent the students in the fairest ways possible and, at the same time, avoid relinquishing our roles in interpreting findings?" (p. 134). And Cook-Sather \& Shultz found the challenge to be one of sharing authority, of sharing the power of speaking and of interpreting what is said, of responding with integrity to a student author who co-wrote a chapter in In Our Own Words and who felt bothered by the fact that this "was going to be a book that really had student voices but then it had to have all this adult interpretation" (Cook-Sather \& Shultz, 2001, p. 175). Most power relationships have no place for listening and actively do not tolerate it, because it is very inconvenient: to really listen means to have to respond. Listening does not always mean doing exactly what we are told, but it does mean being open to the possibility of revision, both of thought and action. At a minimum, it means being willing to negotiate. Old assumptions and patterns of interaction are so well-established that even those trying to break out of them must continue to struggle. And understanding that is part of what it means to listen.

The efforts I review in this section to authorize student perspectives contribute to the project of authorizing student perspectives by offering concrete examples of efforts to have young people frame agendas and guide discussions about education both at the level 
of classroom and in larger conversations. Because formally recognized authorities, such as teacher educators, educational researchers, and publishers, position students at the center of discussions and published texts, these students become authorities as well as authors. This positioning of students is not simply for the sake of discussion; it is with the goal of challenging and changing the most basic premises and practices in education, and it entails a genuine sharing of power and authority. These efforts are also important because and they reveal some of the messiness, complexities, and significant challenges of engaging in attempts not only to attend to student perspectives but to position those students as authorities and to act on what they say.

\section{Looking to Other Professions: Authorizing Clients in Medicine and Law}

Each of the examples outlined above of efforts to challenge the traditional ways in which students have been positioned in relation to their education offers an important dimension to a necessarily multi-dimensional revision of who should be considered an authority on educational theory and practice. These examples offer particularly useful partial answers to questions about the purpose of education, who has the perspective and the power to decide, and how to begin to change assumptions about both. To situate these efforts within the larger world of reform efforts, I turn to recent trends in two other fields, medicine and law, and I briefly outline their changing theories and practices.

Clients in both the medical and the legal realms are very like students in education: they are those whom the profession is intended to serve, but they are often those with the least agency in the service process. For a long time professionals in the medical and legal fields assumed, like educators, that they knew best how to conceptualize and deliver service. Over the last twenty years, however, the provider/client relationship and client satisfaction with service delivered have become a focus of research and practice in the fields of medicine and law.

Many doctors now argue that understanding patients' concerns, expectations, and requests is essential for health care practitioners, policy-makers, and researchers (Kravitz, 2001). Recent research indicates that an increasing number of doctors elicit patients' perspectives both while care is being given (Barr \& Vergun, 2000) and subsequent to 
delivery. There are even some nascent movements toward including patients' assessments of care in the training of medical practitioners (Greco et al., 2000).

Because research finds that positive patient/provider relationships and patient satisfaction are positively associated with quality care (Meredith et al., 2001), many medical researchers advocate not only attending to what their patients want (Mann \& Chambers, 2001) but also promoting patient autonomy built on kindness and respect for the patient as a person (Bruhn, 2001). There is, in fact, an international movement toward "patient-centred" medicine (Stewart, 2001), and research indicates that when patients perceive their care to be patient-centered, the health care provided is more efficient (i.e., there are fewer diagnostic texts and fewer referrals necessary) (Stewart, M., et al., 1995).

Although perhaps less extensive than in medicine and certainly not the mainstream, changes in attitudes toward clients' perspectives in the legal realm have lessons to teach us as well. Like doctors over the last two decades, as early as in the mid1970s, some legal theorists began promoting a "client-centered" legal approach, suggesting that heavy client involvement and control leads not only to higher client satisfaction, but can also, especially for disadvantaged clients, act as a mechanism of empowerment (Rosenthal, 1974; Buss, 1999). This client-centered approach placed itself counter to a traditional lawyer-centered, or paternalistic, approach in which the lawyer acts to serve the client's best interest as he or she constructs it (Hurder, 1996).

This evolving research and attendant changes in medical and legal practice contribute to the project of authorizing student perspectives in education by offering evidence that it is possible to change attitudes and practices, even in professions that have traditionally considered the professional to be the only one with legitimate knowledge and perspective. That doctors and lawyers are beginning to shift their notions of who has authority to comment on practice and how practice might be changed in response to what clients say they want and need further argues for us as educators and educational researchers to do the same. 
Toward More Fully Authorizing Student Perspectives

While each of the efforts I have reviewed thus far has an essential element to contribute toward the goal of expanding the list of who is authorized to analyze educational practice, we must go beyond what has already been accomplished. To better position and prepare all of us to move forward in the $21^{\text {st }}$ century, educators need to embrace more fully the challenge I articulated at the outset of this discussion: to rethink our assumptions about who can and should be an authority on educational practice and both to change existing forums and to create new ones to accommodate conversations among differently positioned authorities on educational practice. Decades of calls for educational reform have not succeeded in making schools places where all young people want to and are able to learn. It is time to invite students to join the conversations about how we might accomplish that.

\section{Rethinking Who Is an Authority on Educational Practice}

If, as Heilbrun contends, "Power is the ability to take one's place in whatever discourse is essential to action and the right to have one's part matter" $(1988, \mathrm{p} .18)$, then students are currently without power in a system that claims to serve them. These power dynamics in the educational system persist because "learning from student voices...requires major shifts on the part of teachers, students, and researchers in relationships and in ways of thinking and feeling about the issues of knowledge, language, power, and self" (Oldfather, 1995, p. 87). Making major shifts in relationships and in ways of thinking requires rejecting the traditional notion that students are empty or evil creatures who need to be filled up, controlled, and contained. It is easy to assert that a first step toward including student perspectives on schooling is counting students among those who belong on the list of stakeholders with a voice in shaping educational policy and practice. It is much harder to actually change the ways we as educators and educational researchers think about and interact with students.

In "The Silenced Dialogue," a discussion of ways in which people of color are left out of conversations about the best ways to educate their children, Delpit suggests that real conversation calls for "a very special kind of listening, listening that requires not only open eyes and ears but also open hearts and minds." She explains: "We do not really 
see through our eyes or hear through our ears, but through our beliefs" (1988, p. 298). It is our basic beliefs that need to change if we are to learn to listen to students. Beliefs about who has authority on educational practice, who can author perspectives on education. We must find a way to listen both openly and critically to students.

A first step in learning to listen, as Delpit also points out, is to stop talking, to stop insisting that we know the answers and to stop asserting them. Alcoff contends that "the effect of the practice of speaking for others is often, though not always...a reinscription... of hierarchies" (1995, p. 250). To break this cycle of re-inscription, educators and educational researchers need to learn "to speak by listening" (Freire, 1998, p. 104). Some of what we hear from students offers inspiring evidence that we should ask more.

High school students who participated in Teaching and Learning Together as part of the teacher preparation program at Bryn Mawr College commented on how their participation illuminated and sometimes changed their sense of themselves and their experiences in school. One student explained that: "[Participating in this project] made me step back as a student and just look at how everything was going on in the classroom. It made me look at how I was being taught and how teachers worked" (Cook-Sather, forthcoming). When students better understand how teachers work — the complement to teachers better understanding how students work - they can participate more constructively in the educational process. Reflecting on her participation in Teaching and Learning Together, another high school student described how her sense of responsibility had changed: "It made me think about how to be a better student 'cause it makes you think that a teacher is up there and they worked hard to come up with this lesson plan and if you're not going to put in a hundred percent then you're letting them down in a way" (Cook-Sather, forthcoming).

When students have the opportunity to articulate their perspectives on school, they not only offer insights into that schooling that are valuable for educators. They also have an opportunity to hone their own thinking — to think metacognitively and critically about their educational experiences. And as a result of this newly gained perspective and investment, students not only feel more engaged. They are also inclined to take more 
responsibility for their education because it is no longer something being done to them but rather something they do.

Of course students do not always have helpful things to say. Sometimes they have nothing to say, sometimes they say things they have not thought through, and always they speak from complex positions — "not single but multiple... always located" (Kamler, 2001 , p. 36). It is a challenge both to the students themselves and to those committed to listening to them to learn both to speak and to listen.

Speaking from his many years of experience working with disenfranchised learners, Freire has a unique authority on this issue. He asserts: "Coherently democratic authority carries the conviction that true discipline does not exist in the muteness of those who have been silenced but in the stirrings of those who have been challenged, in the doubt of those who have been prodded, and in the hopes of those who have been awakened" (1998, p. 86). Students and teachers, researchers and policy-makers, could all participate in this kind of democratic authority if all truly learned to listen to and learn from one another. We could become authorities who are equally heeded regarding teaching and learning, and we would be equally responsible for the actions that make education what it is.

\section{Taking Action with Students for Positive Change}

While our greatest challenge may be to rethink assumptions about who has and who should have power and authority in educational policy-making and practice-shaping, rethinking alone is not enough. We must also create forums within which newly informed conversations about teaching and learning can take place. The elements of the various efforts I have reviewed here must be brought into a complementary balance, woven together into as integrated an approach as possible, and from that new set of understandings and commitments, we must move forward.

From century-old constructivist approaches to education we must retain the notion that students need to be authors of their own understanding and assessors of their own learning. With critical pedagogy we must share a commitment to redistributing power not only within the classroom, between teacher and students, but in society at large. Keeping in mind postmodern feminist critiques of the workings and re-workings of power, we 
must be willing to take small steps toward changing oppressive practices, but we must also continually question our motives and practices in taking these steps. Like the few educational researchers who have included student voices in arguments for how to reform education, we need to include student perspectives in larger conversations about educational policy and practice. Like critics positioned outside the classroom, we need to find ways of illuminating what is happening and what could be happening within classrooms that the wider public can hear and take seriously. And finally, we must include students' as well as adults' frames of reference in conversations about educational policy and practice, and we must take seriously those frames of reference and the assertions made within them as one among several impetuses toward change.

With these commitments, precedents, and nascent efforts as foundation, we can begin to think about next steps. One possibility is using existing forums. As some of the efforts outlined above illustrate, already established forums and publications can expand to include students. To accomplish this expansion there must be "a fundamental shift of the dominant epistemology in our society and our schools to one based on trusting, listening to, and respecting the minds of all participants in schooling" (Oldfather et al., 1999, p. 313).

When educators and educators-to-be learn to listen to students, they can lead the way for others to change. After carrying on an extensive epistolary exchange with a high school student focused on respect, one pre-service teacher who participated in Teaching and Learning Together wrote about how her high student partner taught her that she has "a responsibility to include multiculturalism and diversity in the curriculum." This future physics teacher reflected that "by keeping silent on this issue, I am teaching that only white students can become scientists." Another pre-service teacher gained an equally invaluable insight after reflecting on his exchange with a high school student. This student's eloquence and metacognitive awareness had caused this pre-service teacher "to underestimate my role in helping him to further explain his ideas," but after realizing his misreading, this pre-service teacher took into his career as a social studies teacher a new awareness of his responsibility, which can only be truly fulfilled by listening to students. Two years after participating in Teaching and Learning Together and after teaching for those two years in a middle school, one graduate explained: "I don't think it always 
occurs to teachers to ask students about their opinions. But I do it as a matter of course in my classroom" (Cook-Sather, forthcoming).

The changes in attitude and in practice these pre-service and practicing teachers model are inspiring calls to more fully authorize student perspectives. And yet it is important to acknowledge that such accomplishments are not and cannot be the end of the story. We cannot ever learn, once and for all, to listen. We must continually relearn to listen - in every context, with each group of students and with each individual student. The understanding that each time we will need to learn to listen anew should be as inspiring as it is daunting. It is our opportunity as educators to meet the very challenge we pose to our students: to learn.

Striving to change national contexts for conversation and engage in just this kind of learning, researchers can include students in more presentations at academic conferences and in more publications. Just the mere presence of those who are generally talked about changes those conversations. When we as educational researchers and teachers hear directly from students about their experiences of school, we cannot as easily discuss problems in education and potential solutions in abstract or ideal terms, nor can we as easily dismiss the critical perspectives and the suggestions that students offer. Yet both conference forums and publication processes present challenges. The inclusion of students at conferences presents logistical challenges - securing permission to escort minors and addressing questions about who pays for the students' travel and accommodations, just to name a few. Publication poses other challenges, such as tackling issues concerned with who is in charge of the composing and editing processes in student-generated texts. It is not easy to adjust to the changes required. As one researcher contributor to In Our Own Words put it, "It's not easy and, perhaps, not possible [for us as adults] to simply step aside, and yet the process, though complicated, has generated new and interesting insights" (Cook-Sather \& Shultz, 2001, p. 176-177). The greatest challenge, then, is how to change the terms of the conversation. Heilbrun's words are again relevant: unless students' voices matter and are essential to action, we run the risk of re-inscribing old patterns of power distribution and approaches to change. A step beyond including students in existing forums is the creation of new forums within which all stakeholders can come together and talk amongst themselves, each bringing a 
perspective that is valued and respected by all the others. Like the classroom-based projects, conferences, and publications that foreground student perspectives and invite students to define the terms of discussion, suggest directions, and propose alternatives to the status quo in teaching and learning, we need more forums within which students' critiques of current practices and visions for other possibilities are put first.

Thus among the most basic implications of this call to authorize students perspectives is that there need to be sustained contexts and on-going dialogue about the meaning and nature of education. At the classroom level, at the administrative level, at the school and community levels, and at local and national policy levels, every participant in formal education needs to ask him- or herself where the opportunities for this kind of dialogue exist or could exist within his or her context. Where in the classroom? Where in the school day? Where in the administrative structure? Where at school board meetings? Where in district, state, and national forums? Specific questions educators can ask under the umbrella of this overarching question include:

- With whom do I speak about how education is working and how it might need to change?

- Where does the impetus for changing a curriculum or a form of interaction in school come from, and how can students be more central to that process?

- What are some important barriers to pursuing this change in attitude and practice and how can we address them?

- How might our school's or system's review and reward structures be revised so that attention to student perspectives are not only an integral part of the feedback elicited but so that those perspectives are also a legitimate source upon which to draw in conceptualizing revisions of policy and practice?

Underlying the answers to these questions, which would necessarily vary by context, is the obvious need to rethink the logistical challenges posed by already overly constricting schedules within which all members of the school community labor. Some answers might be relatively easy, such including a question on a standard teaching or administrative evaluation that asks: Did the instructor make changes during the class that were responsive to learning needs expressed by students? If addressing this question, and providing evidence of change based on its answers, were not only legitimate but required 
for review and promotion, the structures that currently support the exclusion of student perspectives from conversations about educational policy and practice would be changed. This move in education would be in keeping with the recognition among other service professionals that they have failed to attend sufficiently to the experiences and perspectives of those whom they aim to serve and the revision of their professional practices to include clients' perspectives in an effort to rectify this failure.

Efforts to attend to student perspectives cannot remain mere add-ons or polite gestures toward listening. Like efforts to reposition students in K-12 classrooms, teacher education, and educational research, we must embed students as authorities in more of the processes that yield to new understandings and in more of the processes of action taken in response. Cognizant of many critiques of power dynamics, I do not believe that power can or should be eliminated from any interaction. What can be changed, however, is who is invested with power and how participants in a class, an institution, or a national debate about educational reform are supported in and rewarded for participation. If, as in some of the projects and publications discussed here, attention to students is not only mandatory but genuine response or follow-through on what is heard is required as well, then we begin to see changes in both conceptual and institutional structures.

There will remain challenges that we will not quickly overcome to including students in forums for conversation about education. Almost all of the challenges reflect what may be a basic human tendency: to fall back consciously or unconsciously on longstanding assumptions and practices, what is familiar and comfortable — or even familiar and uncomfortable. As Britzman (1991) has pointed out, because all of us have spent so many years in school, we think we know what teaching and learning are, and we fall back on what she calls well-worn and commonsensical images that are, in fact, social constructs. The tendency to evoke or simply rely on the assumed in classrooms characterizes many researchers' and policy-makers' impulse to evoke traditional, and therefore generally conservative, categories of analysis. These evocations are often made with the conscious or unconscious goal of disabling efforts to think and act in new ways in the context of educational reform. Britzman's search for "decentering discourses" both within the classroom (Britzman, 1991) and in research approaches (Britzman, 2000) offer us useful ways of jarring ourselves out of the un/comfortable familiar. 
Even as we strive to change current structures and power distribution in education, we must keep in mind the fact that individual students move on. Just as we cannot once and for all learn to listen, we cannot once and for all consult students. This must be an ongoing process. No particular group of students can or should be invested with the responsibility for educational reform. However, all students should be consulted and their words and perspectives included in deliberations about schooling and school reform. It is the collective student voice, constituted by the many situated, partial, individual voices, that we are missing.

Conclusion

If "the first order of reality in the classroom is the student's point of view" (Paley quoted in Evans, 2002, p. 49), then our view of the classroom is far from real. We cannot afford to continue old reform efforts or to develop new ones that do not succeed in making school a place where students want and are able to learn. The authorizing of student perspectives for which I am arguing here is not simply about including students as a gesture. It is about including students to change the terms and the outcomes of the conversations about educational policy and practice. Such a reform cannot take place within the dominant and persistent ways of thinking or the old structures for participation. The terms of the conversations, who participates in them and how, and the ways we act on what comes of the conversations must be reconstituted. As I have argued elsewhere in reference to contexts as disparate as undergraduate teacher preparation (Cook-Sather, 2001a and 2001b) and professional development for college faculty, librarians, and information technologists (Cook-Sather, 2001c), to make education a viable and revitalizing process, we must reconceptualize the roles participants play and we must be willing not only to change the ways we think but also constitute a new language and a new culture for reforming education.

Like those in charge of the health care and legal systems, educators think that we know what education is and should be. Because we have lived longer and have a fuller history to look back upon, we certainly know more about the world as it has been thus far. But we do not know more than students living at the dawn of the $21^{\text {st }}$ century about what it means to be a student in the modern world and what it might mean to be an adult in the future. To learn those things, we need to embrace more fully the work of 
authorizing students' perspectives in conversations about schooling and reform - to move toward trust, dialogue, and change in education. Because of who they are, what they know, and how they are positioned, students must be recognized as having knowledge essential to the development of sound educational policies and practices. Because of who we are, what we know, and how we are positioned, we need to authorize students' perspectives by changing the participant structures as well as the participants in policy-making and practice-shaping conversations about education.

References

Alcoff, L. M. (1995). The problem of speaking for others. In Bell, L. A. \& D. Blumfeld (eds.), Overcoming racism and sexism (pp. 229-254). Lanham: Rowman \& Littlefield.

Alverman, D., Weaver, D., Hinchman, K., Moore, D., Phelps, S., Thrash, E., \& Zalewski, P. (1996). Middle and high school students' perceptions of how they experience text-based discussions: A multi-case study. Reading Research Quarterly, 32, 244-267.

Alverman, D. (1995/1996). Peer-led discussions: Whose interests are served? Journal of Adolescent and Adult Literacy, 39, 282-289.

Alverman, D., Commeyras, M, Young, J., Randall, S., \& Hinson, D. (1997). Interrupting gendered discursive practices in classroom talk about texts: Easy to think about, difficult to do. Journal of Literacy Research, 29, 73-104.

Banks, J. A (ed.) (1996). Multicultural education, transformative knowledge, and action: Historical and contemporary perspectives. New York: Teachers College Press.

Barr, D.D. \& Vergun, P. (2000). Using a new method of gathering patient satisfaction data to assess the effects of organizational factors on primary care quality. Joint Commission Journal on Quality Improvement 26 (12), 713-723.

Britzman, D. (1991). Decentering discourses in teacher education: Or, the unleashing of unpopular things. Boston University Journal of Education 173 (3), 60-80.

Britzman, D. (1991). Practice makes practice: A critical study of learning to teach. New York: State University of New York Press. 
Britzman, D. (2000). "The question of belief:" Writing post-structural ethnography. In E. A. St. Pierre \& W. S. Pillow, (eds.), Working the ruins: Feminist poststructual theory and methods in education (pp. 27-40). New York: Routledge.

Bruhn, J.G. (2001). Equal partners: Doctors and patients explore the limits of autonomy. Journal - Oklahoma State Medical Association 94 (2), 46-54.

Bruner, J. (1977). The process of education. Cambridge: Harvard University Press.

Buss, E. (1999). Confronting developmental barriers to the empowerment of child clients. Cornell Law Review, 84, 895.

Callahan, R. E. (1962). Education and the cult of efficiency: A study of the social forces that have shaped the administration of the public schools. Chicago: University of Chicago Press.

Caporrimo, R. (ed.) (2001). Student perceptions, beliefs, and attitudes. Academic Exchange Quarterly 5 (2).

Clark, C. (1995). Flights of fancy, leaps of faith: Children's myths in contemporary america. University of Chicago Press

Cohen, J. (1993). Constructing race at an urban high school: In their minds, their mouths, their hearts. In L. Weis \& M. Fine (Eds.), Beyond silenced voices: Class, race, and gender in united states schools (pp. 289-308). Albany: State University of New York Press.

Colsant, L. (1995). "Hey, man, why do we gotta take this...? " Learning to listen to students. In J.G. Nicholls \& T.A. Thorkildsen (eds.), Reasons for learning: Expanding the conversation on student-teacher collaboration. New York: Teachers College Press.

Commeyras, M. (1995). What can we learn from students' questions? Theory into Practice, 43 (2), 101-106.

Cook-Sather, A. (forthcoming). Re(in)forming the conversations: Student power, position, and voice in teacher education. Radical Teacher.

Cook-Sather, A. (2001a). Translating themselves: Becoming a teacher through text and talk. In C. M. Clark (Ed.), Talking shop: Authentic conversation and teacher learning (pp. 16-39). New York: Teachers College Press. 
Cook-Sather, A. (2001b). Between student and teacher: Teacher education as translation. Teaching Education, 12 (2), 177-190.

Cook-Sather, A. (2001c). Unrolling roles in techno-pedagogy: Toward collaboration in traditional college settings. Innovative Higher Education, 26 (2), 121139.

Cook-Sather, A.,. \& Shultz, J. (2001a). Starting Where the Learner Is: Listening to Students. In J. Shultz \& A. Cook-Sather (Eds.). In our own words: Students' perspectives on school (pp. 1-17). Latham: Rowman \& Littlefield.

Cook-Sather, A., \& Shultz, J. (2001b). Negotiating Worlds and Words: Writing About Students' Experiences of School. In J. Shultz and A. Cook-Sather (Eds.). In our own words: Students' perspectives on school (pp. 165-178). Latham: Rowman \& Littlefield.

Corbett, H. D. \& Wilson, R. L. (1995). Make a difference with, not for, students: A plea for researchers and reformers. Educational Researcher, 24 (5), 12-17.

Dahl, K. (1995). Challenges in understanding the learner's perspective. Theory into Practice, 43 (2), 124-130.

Davies, B. (1982). Life in the classroom and playground: The accounts of primary school children. Routledge: London Melbourne, Boston and Henley.

Delpit, L. (1988). The silenced dialogue: Power and pedagogy in educating other people's children. Harvard Educational Review, 58 (3), 280-298.

Dewey, J. (1964). My pedagogic creed. In R. D. Archambault (ed.), Dewey on education (pp. 427-439). The University of Chicago Press.

Duckworth, E. (1987). The virtues of not knowing. "The having of wonderful ideas" and other essays on teaching and learning (pp. 64-79). New York: Teachers College Press.

Elder, G. H., Jr. (1995). The life course paradigm: Social change and individual development. In G. Elder, P. Moen, \& K. Luscher (Eds.), Examining lives in context (pp.101-140). Washington D.C.: American Psychological Association.

Ellsworth, E. (1992). Why doesn't this feel empowering? Working through the repressive myths of critical pedagogy. In C. Luke \& J. Gore (Eds.), Feminisms and critical pedagogy (pp. 90-119). New York: Routledge. 
Erickson, F. \& Shultz, J. (1992). Students' experience of curriculum. In P. W. Jackson (Ed.), Handbook of research on curriculum. New York: Macmillan.

Evans, K. (2002). Fifth-grade students' perceptions of how they experience literature discussion groups. Reading Research Quarterly, 37, 46-49.

Finders, M. (1997). Just girls: Hidden literacies and life in junior high. New York: Teachers College Press.

Fine, G. \& Sandstrom, K. (1988). Knowing children: participant observation with minors.

Newbury Park, Calif: Sage Publications.

Fine, M. (1993). Sexuality, schooling, and adolescent females: The missing discourse of desire. In L. Weis \& M. Fine (Eds.) Beyond silenced voices: Class, race, and gender in united states schools (pp. 75-100). Albany: State University of New York Press.

Freire, P. (1998). Pedagogy of Freedom. Latham: Rowman \& Littlefield Publishers, Inc.

Freire, P. (1990). Pedagogy of the oppressed. New York: Continuum.

Friend, R. (1993). Choices not closets: Heterosexism and homophobia in schools. In L. Weis and M. Fine (Eds.), Beyond silenced voices: Class, race, and gender in united states schools (pp. 209-236). Albany: State University of New York Press.

Gallas, K. (1995). Talking their way into science: Hearing children's questions and theories, responding with curricula. New York: Teachers College Press.

Garbarino, J. \& Scott, F. (1989). What children can tell us. San Francisco: JosseyBass Inc.

Garcia, F., Kilgore, J. Rodriquez, P. \& Thomas, S. (1995). "It's like having a metal detector at the door": A conversation with students about voice. Theory into Practice, 43 (2), 138-144.

Giroux, H. (1992). Border crossings: Cultural workers and the politics of education. New York, London: Routledge

Gore, J. (1993). The struggle for pedagogies: Critical and feminist discourses as regimes of truth. New York: Routledge. 
Gore, J. (1992). What can we do for you? What can "we" do for "you"?: Struggling over empowerment in critical and feminist pedagogy. In Luke, C. \& Gore, J. (Eds.), Feminisms and Critical Pedagogy. New York: Routledge.

Greco, M., Brownlea, A. McGovern, J. \& Cavanagh, M. (2000). Consumers as educators: Implementation of patient feedback in general practice training. Health Communication 12 (2), 173-193.

Greig, A. \& Taylor, J. (1999). Doing research with children. Sage: London, Thousand Oaks: New Delhi.

Heilbrun, C. (1988). Writing a woman's life. New York: Ballantine Books.

Herbart, J.F. (1901). Outlines of educational doctrine. Trans., Alexis F. Lenge. New York: The Macmillan Company.

Heshusius, L. (1995). Listening to children: "What could we possibly have in common?" From concerns with self to participatory consciousness. Theory into Practice, 43 (2), 117-123.

hooks, b. (1994). Teaching to transgress: Education as the practice of freedom. New York: Routledge.

Hudson-Ross, S. Cleary, L. \& Casey, M. (1993). Children's voices: Children talk about literacy. Heineman Portsmouth $\mathrm{NH}$

Hurder, A. J. (1996). Negotiating the lawyer-client relationship: A search for equality and collaboration. Buffalo Law Review, 44, 71.

Johnston, P. \& Nicholls, J. (1995). Voices we want to hear and voices we don't. Theory into Practice, 43 (2), 94-100.

Kamler, B. (2001). Relocating the personal: A critical writing pedagogy. New York: State University of New York Press.

Kliebard, H. M. (1986). The struggle for the american curriculum, 1893-1958. Boston: Routledge \& Kegan Paul.

Knowledge Quest, 30, 5. May/June, 2002. The American Association of School Libraries.

Kotlowitz, A. (1991). There are no children here: The story of two boys growing up in the other america. New York: Doubleday. 
Kozol, J. (1991). Savage inequalities: children in america's schools. New York: Harper Perennial.

Kravitz, R.L. (2001). Measuring patients expectations and requests. Annals of Internal Medicine 134 (9), (Part 2), 881-888.

Ladson-Billings, G. (1994). The dreamkeepers: Successful teachers of african american children. San Francisco: Jossey-Bass.

Lensmire, T. J. (1994). When children write: Critical revisions of the writing workshop. New York: Teachers College Press.

Lewis, C. (2001). Literacy practices as social acts: Power, status, and cultural norms in the classroom. Mahwah, NJ: Erlbaum.

Lewis, M. (1993). Without a word: Teaching beyond women's silence. New York:

Routledge.

Light, R. (2001). Making the most of college: Students speak their minds. Cambridge: Harvard University Press.

Lincoln, Y. (1995). In search of students' voices. Theory into Practice, 43 (2), 8893.

Locke, J. (1823). Some thoughts concerning education. In Works of john locke. London: Thomas Tegg, et al. Vol. IX.

Mann, L. \& Chambers, D. (2001). Designing a consumer friendly practice. Australian Family Physician 30 (3), 241-244.

McLaren, P. (1989). Life in schools: An introduction to critical pedagogy in the foundations of education. New York \& London: Longman.

Meredith, L.S. et al. (2001). Are better ratings of the patient-provider relationship associated with higher quality care for depression? Medical Care 39 (4), 349-360.

Moje, E., \& Shepardson, D. (1998). Social interactions and children's changing understanding of electric circuits: Exploring unequal power relations in "peer"-learning groups. In B. Guzzetti \& C. Hynd (Eds.), Perspectives on conceptual change (pp. 225234). Mahwah, NJ: Erlbaum.

Nespor, J. (1997). Tangled up in school: Politics, space, bodies, and signs in the educational process. Mahwah, N.J: L. Erlbaum Associates. 
Nicholls, J. \& Thorkildsen, T. (1995). Reasons for learning: Expanding the conversation on student-teacher collaboration. New York: Teachers College Press, Teachers College, Columbia University.

Nieto, S. (2000). Affirming diversity: The sociopolitical context of multicultural education. New York: Longman.

Oldfather, P., Thomas, S., Eckert, L., Garcia, F., Grannis, N., Kilgore, J., et al. (1999). The nature and outcomes of students' longitudinal research on literacy motivations and schooling. Research in the Teaching of English 34, 281-320.

Oldfather, P., \& Thomas, S. (1998). What does it mean when teachers participate in collaborative research with high school students on literacy motivations? Teachers College Record 90 (4), 647-691.

Oldfather, P. (ed.), (1995). Learning from student voices. Theory into Practice, 43 (2).

Oldfather, P. (1995). Songs “come back most to them": Students' experiences as researchers. Theory into Practice, 43 (2), 131-137.

O'Loughlin, M. (1995). Daring the imagination: unlocking voices of dissent and possibility in teaching. Theory into Practice, 43 (2), 107-116.

Orner, M. (1992). Interrupting the calls for student voice in "liberatory" education: A feminist poststructuralist perspective. In C. Luke \& J. Gore (Eds.), Feminisms and critical pedagogy. New York: Routledge.

Phelan, P, Davidson, A.L. \& Cao, H.T. (1992). Speaking up: Students' perspectives on school. Phi Delta Kappan, 73 (9), 695-704.

Phelan, P., Davidson, A.L. \& Yu, H.C. (1998). Adolescents' worlds: Negotiating family, peers, and school. New York: Teachers College Press.

Pope, D. C. (2001). Doing school: How we are creating a generation of stressed out, materialistic, and miseducated students. New Haven, CT: Yale University Press.

Poplin, M. \& Weeres, J. (1992). Voices from the inside: A report on schooling from inside the classroom. Claremont, CA: Claremont Graduate School, Institute for Education in Transformation.

Rosenthal, D. E. (1974). Lawyer and client: who's in charge?. New York: Russell Sage Foundation. 
Rosseau., J. J. (1965). Emile. In The emile of jean jaques rosseau: Selections. William Boyd, ed. New York: Teachers College Press.

Sachs, S. B. (2002). Voices of reason: Adolescents talk about their futures over time. Westport, CT.: Bergin \& Garvey.

Sanon, F., Baxter, M., Fortune, L. \& Opotow, S. (2001). Cutting Class: Perspectives of Urban High School Students. In J. Shultz \& A. Cook-Sather (Eds.), In our own words: Students' perspectives on school (pp. 73-91). Latham: Rowman \& Littlefield.

Shor, I. (1987). Freire for the classroom: A sourcebook for liberatory teaching. Portsmouth: Heinemann.

Shor, I. (1992). Empowering education: Critical teaching for social change. The University of Chicago Press.

Shultz, J. \& Cook-Sather, A. (eds.) (2001). In our own words: Students' perspectives on school. Latham: Rowman \& Littlefield.

Skinner, B. F. (1969). Contingencies of reinforcement: A theoretical analysis. New York: Appleton-Century-Crofts.

Spring, J. H. (1976). The sorting machine: National educational policy since 1945. New York: McKay.

Stewart, M. (2001). Towards a global definition of patient centred care: The patient should be the judge of patient centred care. British Medical Journal 322 (7284), 444-445.

Stewart, M. et al. (1995). Patient-centred medicine transforming the clinical method. Thousand Oaks: Sage Publications.

Walker, B. (1998). "Childhood" in the Emergence and Spread of U.S. Public Schools. In T.S. Popkewitz \& M. Brennan (eds.), Foucault's challenge: Discourse, knowledge, and power in education (pp.117-143). New York: Teachers College. Walsh, D., Tobin, J. \& Graue, M. (1993). The interpretive voice: Qualitative research in early childhood education. In B. Spodek (Ed.), Handbook of research on the education of young children (pp. 464-474). New York: Macmillan.

Weis, L. \& Fine, M. (Eds.) (1993). Beyond silenced voices: Class, race, and gender in united states schools. Albany: State University of New York Press. 
Welch, S. (1990). A feminist ethic of risk. Minneapolis: Fortress Press.

Wilson, B. L. \& Corbett, H. D. (2001). Listening to urban kids: School reform and the teachers they want. New York: State University of New York Press.

Willis, P. (1997). Learning to labour: How working class kids get working class jobs. Farnborough, Eng.: Saxon House. 